\title{
AGE AND GROWTH OF THE DUCKBILL CATFISH (Sorubim cf. lima) IN THE PANTANAL
}

\author{
PENHA, J. M. F., ${ }^{1}$ MATEUS, L. A. F. ${ }^{2}$ and BARBIERI, G. ${ }^{3}$ \\ ${ }^{1}$ Departamento de Botânica e Ecologia, IB, Universidade Federal de Mato Grosso, CEP 78060-900, \\ Cuiabá, MT, Brazil \\ ${ }^{2}$ Departamento de Producão Animal, FAMEV, Universidade Federal de Mato Grosso, CEP 78060-900, Cuiabá, MT \\ ${ }^{3}$ Instituto de Pesca, Centro para Estudos de Bacias Hidrográficas, Avenida Francisco Matarazzo, 455, \\ CEP 05001-900, São Paulo, SP, Brazil \\ Correspondence to: Jerry M. F. Penha, Departamento de Botânica e Ecologia, IB, Universidade Federal de Mato \\ Grosso, CEP 78060-900, Cuiabá, MT, Brazil, e-mail: jerrym@ @erra.com.br \\ Received November 5, 2002 - Accepted February 4, 2003 - Distributed February 29, 2004
}

(With 4 figures)

\begin{abstract}
The Duckbill Catfish, Sorubim lima, is a predator of large South American rivers. The age and growth of S. lima were studied based on the pectoral fin-spines of samples collected from the Cuiabá River, Pantanal. The samples were taken from commercial and experimental hook-and-line fishing. An analysis of the marginal increment suggests that the growth rings are formed once a year during the dry season, from July to September (ANOVA type I: $F=4.183 ; g . l .=3$ and $104 ; \mathrm{p}=0.008$ ). The estimate of the parameters that describe von Bertalanffy's growth curve by nonlinear regression of the observed lengths in the age were: $L_{\infty}=56.0 \mathrm{~cm}$ (fork length); $k=0.245 \mathrm{year}^{-1} ; t_{o}=-2.605$ years. The animals were estimated to have a life span of 9.6 years. The findings indicate that the fork length is a good predictor of the age of individuals of this fish species.
\end{abstract}

Key words: Duckbill Catfish, age, growth, fin spine, Sorubim lima, Pantanal.

\section{RESUMO}

\section{Idade e crescimento do Jurupensém (Sorubim cf. lima) no Pantanal}

O Jurupensém, Sorubim lima, é um predador dos grandes rios da América do Sul. A idade e o crescimento do $S$. lima foram estudados a partir de espinhos de nadadeiras peitorais de exemplares coletados no Rio Cuiabá, Pantanal Mato-grossense. Os exemplares provieram da pesca comercial e experimental, com linha e anzol. A análise do índice de incremento marginal sugere que os anéis de crescimento se formam uma vez ao ano, durante a estação da seca, entre julho e setembro (ANOVA tipo I: $F=$ 4,$183 ;$ g.l. $=3$ e $104 ; \mathrm{p}=0,008$ ). Os parâmetros que descrevem a curva de crescimento de von Bertalanffy, ajustados por meio de regressão não-linear aos comprimentos observados na idade, foram estimados em: $L_{\infty}=56,0 \mathrm{~cm}$ (comprimento furcal); $k=0,245 \mathrm{ano}^{-1} ; t_{o}=-2,605$ anos. A longevidade dos indivíduos foi estimada em 9,6 anos. Os resultados indicam que o comprimento furcal é um bom preditor de idade para os indivíduos dessa espécie de peixe.

Palavras-chave: idade, crescimento, Sorubim lima, Pantanal, Jurupensém.

\section{INTRODUCTION}

The Pimelodidae family encompasses important predators of large South American rivers. These predators constitute a considerable portion of the catch of all regional inland fishing (Novoa, 1982; Ferraz de Lima \& Chabalin, 1984; Ferraz de Lima, 1986; Bayley \& Petrere Jr., 1989; Petrere Jr., 1989; Ribeiro et al., 1995; Muñoz-Sosa, 1996; Alonso, 1998; Catella, 2001; Petrere Jr. et al., 2002). As a member of the Pimelodidae family, the genus Sorubim comprises four species of deepwater catfish (Froese 
\& Pauly, 2002): S. elongatus, which lives in the basins of the Amazon, Essequibo, and Orinoco rivers (Littmann et al., 2001); S. cuspicaudus, in the basins of the Magdalena, Maracaibo, and Sino rivers (Froese \& Pauly, 2002); S. trigonocephalus, in the Madeira and Tapajós rivers (Burgess, 1989); and S. lima, which is the most widely distributed species, occupying the basins of the Amazon, Orinoco, Paraná, and Parnaíba rivers (Froese \& Pauly, 2002).

The S. lima is one of the largest predators of the rivers flowing through the Pantanal, with a maximum standard length of $55 \mathrm{~cm}$ (Britski et al., 1999). Although this species is sold in the regional markets, there is no record of landings in the northern portion of the Pantanal. Landings data in the southern portion indicate that the total catch of this species in 1999 was 21 tons. The accumulated catch of the period between 1994 and 1999 was 99 tons (Catella, 2001).

Despite the importance of this species for ecosystem functioning and for the regional economies it inhabits, little is known about its biology. This study consisted of estimating the age and growth of S. lima based on a count of the rings on the pectoral fin-spines. Pectoral fin-spines are structures easily available in fish markets, since their removal does not affect price. So that, in addition to being validated for several fish species (Brennan \& Cailliet, 1989; Rien \& Beamesderfer, 1994; McFarlane \& King, 2001), this technique offers a relatively low-cost solution. The objective of the present study was determining the age, and estimating the parameters of the von Bertalanffy growth curve and the longevity of individuals of this species, as an aid in developing strategies for its management.

\section{MATERIAL AND METHODS}

\section{Study area}

The Pantanal, wetland formed by the seasonal flooding of the Paraguay River and its tributaries, comprises an area of approximately $140,000 \mathrm{~km}^{2}$ located between latitudes $55^{\circ}$ and $58^{\circ}$ and longitudes $16^{\circ}$ and $22^{\circ}$ (Da Silva, 2000). Most of the Pantanal is located in the states of Mato Grosso and Mato Grosso do Sul in Brazil; smaller portions are in Bolivia and Paraguay.
The fishes used for this study were collected from the Cuiabá River, one of the largest tributaries of the Paraguay River, in the northern part of the Pantanal. The region is in a humid and hot climatic zone, with rainy summers and dry winters (Köppen, 1948). The rainfall pattern creates four hydrological periods: the rising water period (normally lasting from October to December), the flooding period (usually January to March), the receding water period (generally from April to June), and the dry period (commonly from July to September) (Da Silva \& Esteves, 1995). However, these periods may be delayed by up to two months as the distance from the rivers increases (Heckman, 1994).

\section{Sampling procedure and data analysis}

Measurements from Duckbill Catfish $(n=211)$ were registered between April 2000 and October 2001. Most of the individuals $(n=166)$ were collected monthly between April and October 2000 and in March, April, and October 2001, from the Antônio Moysés Nadaf street market in the city of Cuiabá, Mato Grosso. Owing to the reproductive season during which fishing is forbidden, additional samples $(n=45)$ were collected by means of experimental fishing between November 2000 and February 2001. All the samples were taken from fish caught with hook and line.

Using a knife, the left pectoral fin-spine was extracted from each fish, placed in numbered plastic bags, and frozen for subsequent analysis. The following measurements from each fish were recorded: total length $(L t-\mathrm{cm})$, fork length $(L f)$, total weight $(W t-\mathrm{g})$, and eviscerated weight $(W e)$. The lengths were measured to the closest centimeter, and the weight to the closest gram. The spines were washed in running water, immersed in commercial acetone for 24 hours, and transferred to hot water (around $50^{\circ} \mathrm{C}$ ). This procedure helped remove adhered tissue. The length and diameter at the proximal portion of each spine were then measured with the aid of a ruler and a vernier caliper. Three to six cross sections were made at the base of each spine, with thicknesses varying from 0.4 to $1 \mathrm{~mm}$, using a rock cutting saw with a diamond disc manufactured by Wolfgang Conrad ClausthalZellerfeld. The sections were immersed in $70 \%$ 
alcohol on petri dishes. Readings and measurements were carried out under a Carl Zeiss (Jena) stereomicroscope with a micrometric lens, 40 times magnification, and incident light. Sections with marks that were difficult to view were polished.

The sections revealed wide opaque zones alternating with narrow translucent ones. The opaque zones were considered indicative of rapid growth periods while the translucent ones indicated periods of slow growth (Casselman, 1983). A complete welldefined translucent zone was considered to be a growth ring (or annulus), while an unclear, irregular, or incomplete translucent zone was considered a false mark (Casselman, 1983). Two complete translucent marks, whose distance from each other was less than the distance from the preceding and following marks, were considered a double mark (Megalofonou, 2000). All growth rings were counted, and their radii at zero degree - the distance from the center of the spine to the ring - were measured (Fig. 1). Only spines in which the number of growth rings was repeated in at least two sections were included in the analysis.

A problem commonly encountered when fin spines are used to determine the age of fish is that the cores of these structures may be reabsorbed as the fish ages (Casselman, 1983). The core is replaced by a hole that may cause the first growth rings to disappear, leading to age underestimations (Casselman, 1983). In the present study, the evidence of reabsorption of the first ring through the appearance of holes in older individuals was evaluated by KruskalWallis's nonparametric test (Sokal \& Rohlf, 1995). The decision to analyze the data using a nonparametric test was based on non-normality of the residues. The analysis was conducted considering the age (number of rings) as a factor and the radius of the first ring at $0^{\circ}(\mathrm{Rz})$ as a response variable. The a posteriori comparisons were made using the $Q$-test (Zar, 1996). In the presence of the phenomenon of reabsorption of the first ring, individuals from older age groups should show larger first ring radii than individuals from younger age groups.

To validate the rings as indicators of the fish's age, ring count and measurement data were subjected to two indirect analyses (Lai et al., 1996). The first consisted of evaluating whether the rings on the spine could be considered indicators of the fish's growth. To be considered a growth indicator, the number of rings must show a directly proportional relation to spine size and fish length. To define whether the number of rings varies with spine size, a visual inspection is made of a box-plot correlating ring number and spine radii. This correlation is particularly important for back-calculation. The correlation between spine size and Lf was investigated by linear regression. The second analysis consisted of determining the period of formation of the annuli which, in the present study, was investigated by marginal increment analysis (MI) (Lai et al., 1996):

$$
\mathrm{MI}=\left(\mathrm{R}-\mathrm{r}_{\mathrm{i}}\right) /\left(\mathrm{r}_{\mathrm{i}}-\mathrm{r}_{\mathrm{i}-1}\right) * 100
$$

where $R$ represents spine radius, and $r_{i}$ and $r_{i-l}$ annular radii of the last and penultimate annuli, respectively. The $M I$ differences were evaluated by one-way ANOVA (Sokal \& Rohlf, 1995). Owing to the small number of observations, the comparisons were conducted on seasonal MIs of individuals having 2 and 3 annuli. The a posteriori analyses were carried out using the Tukey test (Sokal \& Rohlf, 1995). The period of annuli formation was considered the one for which the $M I$ displayed the smallest value.

The total weight versus fork length relationship was adjusted by non-linear regression. The non-linear adjustment was based on the minimum squares method, Gauss-Newton algorithm.

To carry out the back-calculation, an analysis was first made to determine whether the correlation between the spine's zero degree radii $(z d r)$ and the $L f$ was linear. Three regression models were tested: the potential $\left(L f=a(z d r)^{b}\right)$, exponential $\left(L f=a e^{b(z d r)}\right)$, and linear $(L f=a+b(z d r))$. The decision about which of the models best fit the data was based on a joint analysis of the coefficient of determination $\left(r^{2}\right)$ and the residual variance (SQM). The functional regression parameters were then estimated, following the procedure described by Ricker (1992). FraserLee's equation was used to back-calculate the size of the fish at the time when the annuli were formed (Francis, 1990):

$$
\mathrm{Li}=\mathrm{c}+(\mathrm{Lc}-\mathrm{c})(\mathrm{Si} / \mathrm{Sc})
$$

where $L i$ is length at time of annuli formation ( $i=$ $1,2,3, \ldots, \mathrm{n}) ; c$ is the intercept of the regression between body size versus spine size, estimated by the functional regression; $L c$ is length of fish when caught; and $S i$ and $S c$ are the annuli-radius $i$ and the total radius of spine at capture, respectively. 


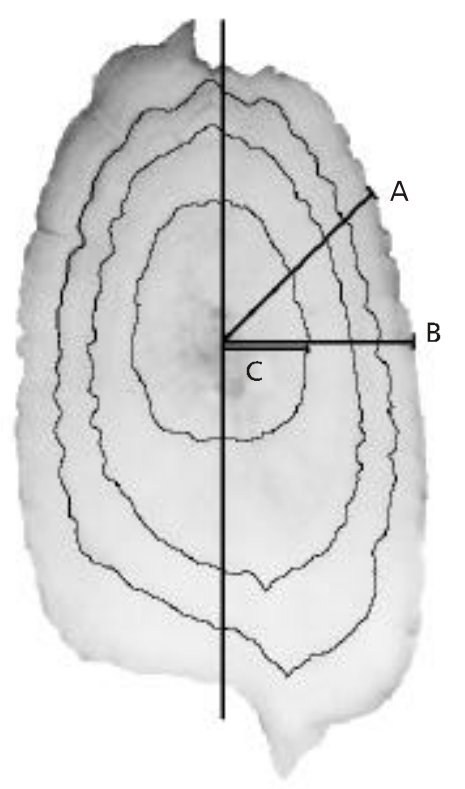

Fig. 1 - Schematic drawing of the pectoral fin-spine of $S$. lima, showing the measurements taken: $\mathrm{A}=$ radius at $45^{\circ} ; \mathrm{B}=$ radius at $0^{\circ} ; \mathrm{C}=$ radius of the first ring.

In order to describe the species' growth, von Bertalanffy's growth model (Bertalanffy, 1938) was adjusted to the lengths at each age, both observed and back-calculated. The parameters of the equation were estimated by nonlinear regression using the minimum squares method, Gauss-Newton algorithm. The parameters of the growth curve were subsequently used to produce an estimate of the longevity of individuals in the stock. For this purpose, the Taylor method (Taylor, 1957) - which estimates the average time required for the individuals of the stock to reach $95 \%$ of the $L_{\infty}$ - was used.

$$
\mathrm{A}_{0,95}=\mathrm{t}_{0}+2,996 / \mathrm{k}
$$

All the statistical analyses were conducted using the SYSTAT software program (SYSTAT, 1997).

\section{RESULTS}

The results indicate that pectoral fin-spines of $S$. lima are appropriate structures for annuli counts. Of the 211 spines analyzed, 205 (97\%) showed visible annuli. In some cases, the sections displayed grooves, with marks crossing over the rings from the core to the edge of the spine; in others, the rapid growth zones were more translucent. However, the annuli stood out even in such situations. From the total number of spines with visible annuli $(n=205)$, $63 \%$ displayed only single ones, while 37 showed double marks as well as single annuli; $44.5 \%$ of the spines also displayed false marks. These false marks appeared more commonly between the second and fifth annuli, while the double marks were present between the first and second annuli. Although annuli were detected on 205 spines, only in 197 (93.5\%) of them were the number of annuli repeated in at least 2 sections. Therefore, only data from the readings of these 197 spines were considered reliable and used in subsequent analyses.

The sample used in this study comprised individuals with $L f$ varying from 23 to $53.5 \mathrm{~cm}$. The mean size of the individuals of the sample $\left(L f_{\text {mean }}\right)$ was $39.64 \mathrm{~cm}$, with standard error (s.e.) of 0.46 . The spines showed up to 5 annuli, representing 5 age groups; the predominating age class had 3 annuli. The mean age $\left(t_{\text {mean }}\right)$ was 2.55 annuli $($ s.e. $=0.074)$ and the median $\left(t_{\text {median }}\right)$ was 3 annuli. 
No evidence was found of reabsorption of the first annulus of older individuals through the appearance of a hole in the core of the spine. The Kruskall-Wallis test revealed significant differences among the age groups $(H=26.064 ;$ g.l. $=4 ; \mathrm{p}=0.000)$. The $Q$-test for comparisons of a posteriori ranks indicated that age groups 1 and 2 had larger first annulus radii than did groups 3 and 4 , and that group 5 did not significantly differ from the other groups. This finding was contrary to what was expected in the presence of the phenomenon of reabsorption of the first annulus in older age groups and, hence, increased the reliability of the readings done on the rings.

The analyses of the correlations between the numbers of rings, the size of the spine and $L f$ indicated that the rings on the spines were, indeed, indicators of growth. The visual analysis of the box-plot between spine radius and ring number indicated that the larger spines contained more annuli (Fig. 2).

In addition to this important conclusion, the linear models indicated that larger individuals had larger spines. The variation in fork length explained $85 \%$ of the variation in spine length and $84 \%$ of the variation in diameter, as well as $69 \%$ of the variation of spine $z d r$ and $63 \%$ of the variation in the $45^{\circ}$ radius (Fig. 3). In short, a positive correlation was found between the number of annuli in the spines and the size of the individuals from which those spines were extracted.

The spine's border growth data indicated that growth marks are formed annually during the dry season. Owing to the non-normality of the residues, the tests were conducted using the square root of the data. This transformation was used because it was the only one that normalized the residues. The ANOVA test revealed significant differences between the seasonal MIs (one-way ANOVA: $F_{\text {obs }}=4.183$; g.l. $=3$ and $104 ; \mathrm{p}=0.008)$. The ANOVA was validated through an analysis of the residues, which indicated its normality $(g 1=0.166 ; g 2=-0.266$; p > 0.05; $n=108$ ) and Bartlett's test, which showed homoscedasticity of variances $\left(X^{2}=2.375 ;\right.$ g.l. 3 ; $\mathrm{p}>0.05)$. Lastly, the a posteriori Tukey test indicated that the MIs in the dry season were significantly smaller than those in the rising water season $(n=$ $108 ; \mathrm{p}=0.003$ ).

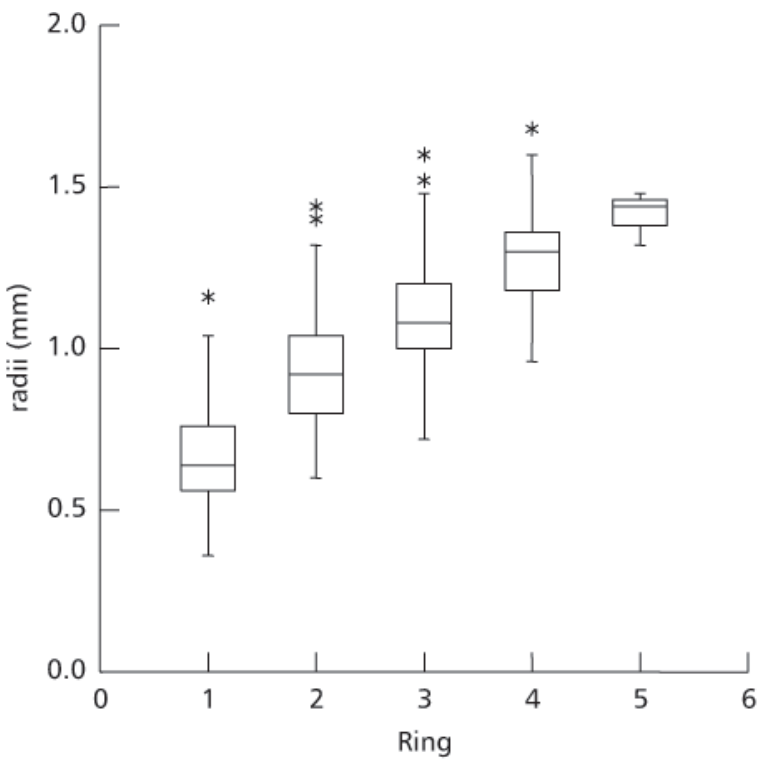

Fig. 2 - Box-plot of the correlation between the radius of the spine at $0^{\circ}$ and the number of growth rings in the cuts. The upper portion of the boxes is given by the third quarter and the lower one is given by the first. The horizontal line passing through the box represents the median. The vertical bar indicates the minimum and maximum values. The stars indicate discrepant observations. 

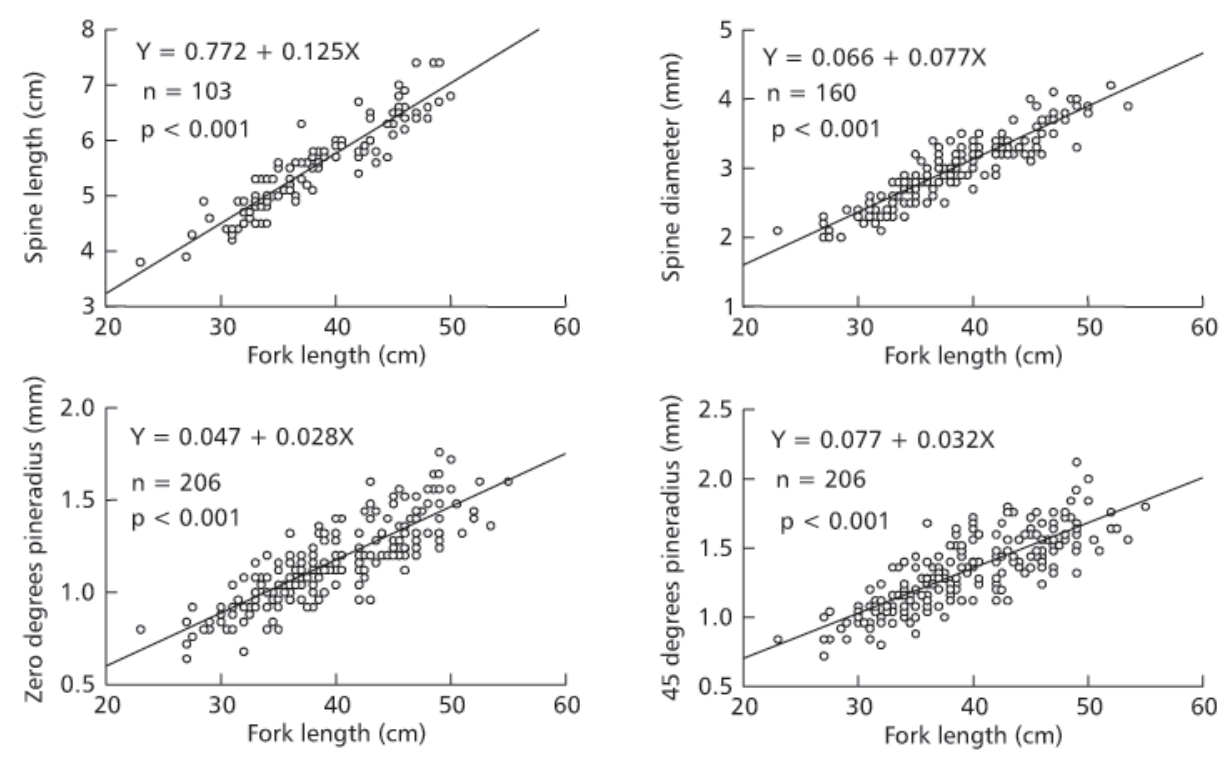

Fig. 3 - Correlation between the characteristic associated with the size of the spine and the fork length of S. lima from the Cuiabá River.

Considering that $S$. lima spawns at the onset of the rainy season in several South American rivers and, hence, at the beginning of the rising water period (Goulding, 1981; Vazzoler et al., 1997; Mago, 1970, apud Lowe-McConnell, 1999), spawning in the Pantanal should occur sometime between October and December. If this inference is correct, the first annulus is formed between the $7^{\text {th }}$ and $11^{\text {th }}$ month of the cohort's life. However, since the environmental conditions tend to deteriorate as the dry season progresses, becoming critical towards the end, the first annulus most likely appears, on average, 1 year after the cohort's birth.

The relationship between $W t$ and $L f$ was described by a power function $\left(W t=0.001 * L f^{3.457}\right)$. The variation in $L f$ explained $93 \%$ of the variation in $W t$. The value of the $b$ of the $W t-L f$ relationship, estimated at 3.457 , is considerably greater than 3 (confidence interval for the estimated $b=3.275$ to 3.639). This figure indicates that $S$. lima increases its weight at a rate exceeding that required to maintain a constant corporal proportion.

The analyses of residual variances and coefficients of determination indicate that all the models described the correlation between the spine's $L f$ and $z d r$ consistently $\left(r^{2}\right.$ : power $=0.692$; exponential $=0.67$; and linear $=0.688$ ). Therefore, the simplest model - the linear - was chosen as the one that best describes this correlation in S. lima $(Y=11.194+24.483 X ; n=206 ; \mathrm{p}<0.001)$.

Fraser-Lee's equation produced consistent results. As expected, the back-calculated lengths were shorter than those observed, the differences decreasing with age (Table 1). Nevertheless, the average length attained in the cohort's first year, shown in column Lfl of Table 1, decreased with the age of the cohort from which it was estimated, the only exception being the oldest cohort, for which there were the least number of observations, and thus less reliable estimates. This fact suggests the presence of the RosaLee phenomenon (Lee, 1912, apud Ricker, 1969). When this is present, the average calculated size of the younger fish is smaller, the older the fish from which it was estimated (Ricker, 1969, 1979).

The use of back-calculated data increased the precision of the estimates (smaller asymptotic standard error - A.S.E.). Nevertheless, the $L_{\infty}$ value estimated with these data $\left(L_{\infty}=46.5 \mathrm{~cm} ; A . S . E .=\right.$ 3.294) was considered well below the average size of the larger individuals of the sample $(53.5 \mathrm{~cm})$ and, hence, biologically unreal. Thus, we consider that the best estimate of the growth parameters was generated with the use of the lengths observed $\left(r^{2}=\right.$ 0.41). The values of $k=0.245$ year $^{-1}($ A.S.E. $=0.165)$ 
e $L_{\infty}=56.0 \mathrm{~cm}($ A.S.E. $=11.032)$ estimated with these data are considered typical of a slow-growing species (Fig. 4).

The estimates of the $L f$ reached in the first year of life varied from $26.9 \mathrm{~cm}$, using back-calculated data, to $32.8 \mathrm{~cm}$, using observed data. Therefore, although the species approaches its $L_{\infty}$ slowly, its initial growth is fast.

The longevity $\left(A_{0.95}\right)$ of the individuals in stock was estimated at 9.6 years.

TABLE 1

Mean fork length values $(L f)$ at back-calculated ages. The highlighted values are the mean lengths of the cohorts.

\begin{tabular}{|c|c|c|c|c|c|c|c|}
\hline $\mathbf{N}$ & $\boldsymbol{L f}_{\text {obs. }}$ & Age & $\boldsymbol{L f}_{\boldsymbol{1}}$ & $\boldsymbol{L} \boldsymbol{f}_{\mathbf{2}}$ & $\boldsymbol{L} \boldsymbol{f}_{\mathbf{3}}$ & $\boldsymbol{L f}_{\boldsymbol{4}}$ & $\boldsymbol{L} \boldsymbol{f}_{\boldsymbol{5}}$ \\
\hline 37 & 32.703 & 1 & $\underline{26.46}$ & & & & \\
\hline 55 & 38.191 & 2 & 26.356 & $\underline{35.185}$ & & & \\
\hline 69 & 41.529 & 3 & 23.569 & 32.241 & $\underline{37.573}$ & & \\
\hline 32 & 45.094 & 4 & 22.651 & 31.424 & 38.083 & $\underline{42.151}$ & \\
\hline 4 & 47.500 & 5 & 25.72 & 34.504 & 39.439 & 42.754 & $\underline{45.26}$ \\
\hline Mean & & 24.785 & 33.146 & 37.8 & 42.218 & 45.26 \\
\hline Increment & 24.785 & 8.361 & 4.654 & 4.418 & 3.042 \\
\hline $\mathrm{N}$ & 197 & 160 & 105 & 36 & 4 \\
\hline
\end{tabular}

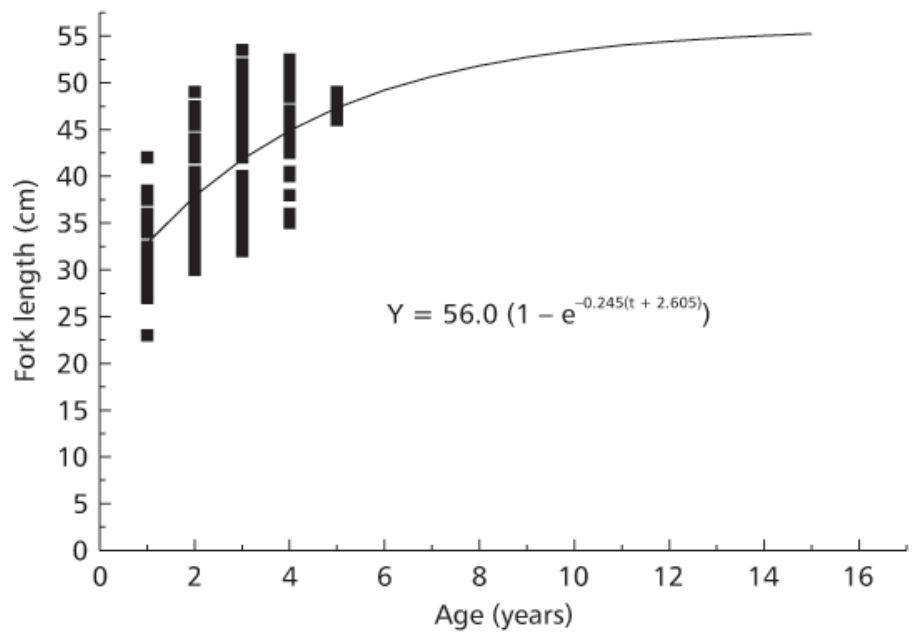

Fig. 4 - Growth curve in length for Sorubim lima from the basin of the Cuiabá River, Pantanal, Mato Grosso, Brazil. 


\section{DISCUSSION}

The results indicate that the pectoral fin-spine is a suitable structure by which to evaluate the age of S. lima. The positive correlation between the number of annuli and the $L f$ indicates that the former express the fish's growth. Besides this characteristic, the annuli on the spine can be identified confidently. The spines of old fish were generally more difficult to interpret. However, although reabsorption of the core may occur in this age group, the greatest difficulty involved separating the more recently formed rings. As Casselman (1983) pointed out, in some cases the distal translucent zones may be so close to each other than they seem to coalesce, rendering it difficult or even impossible to obtain a good optical resolution and to correctly evaluate the number of annuli. Nonetheless, this same author states that the identification of growth marks on fish scales and spines becomes more inconsistent from the $6^{\text {th }}$ mark on (Casselman, 1983). Since 5 was the maximum number of annuli observed here, the readings can be considered reliable.

The analysis of the marginal increment indicated that the growth rings on the spine of $S$. lima are formed once a year during the dry season. This pattern was also found for other Pimelodidae, such as the Pseudoplatystoma corruscans in the Pantanal (Resende et al., 1996; Mateus \& Petrere Jr., in press), the $P$. fasciatum and $P$. tigrinum in the Apure River (Reid, 1983) and in the Bolivian Amazon (Loubens \& Panfili, 2000), the Pimelodus maculatus in the Paraná River Basin (Fenerich et al., 1975), the Paulicea lüetkeni of the Meta River (Reina et al., 1995), and the Brachyplatystoma filamentosum and B. flavicans of the Colombian Amazon (Muñoz-Sosa, 1996). On the other hand, the Amazonian Calophysus macropterus forms two annual growth rings: one in August as the river waters recede, and the other in January, as the rivers rise (Pérez Lozano, 1999). The ring formed during the receding is assumed to be associated with migration, and the one formed during the rising, to reproduction (Pérez Lozano, 1999).

The studies cited in the previous paragraph and others listed by Lowe-McConnell (1999) and Welcome (1992) suggest that low temperature, drought, and reproductive activity are critical events affecting the growth of fish in large river systems with floodplains. However, elucidation of the causes leading to annuli formation on the pectoral fin-spines of S. lima inhabiting the Cuiabá River is a complex one, owing to the temporal overlap of the winter, the dry season, and the reproductive migration. Thus, progressive deterioration of water quality and the probable food scarcity during the dry season, allied to the energy investment required in reproductive migration, appear to be the main factors influencing the formation of growth rings in this fish species.

These conclusions about the period of formation of growth marks should be viewed cautiously. A large part of the studies were validated using the marginal increment. As pointed out by Campana (2001), the marginal increment is a problematic validation method because it depends on the accurate identification of rings located on a structure's edge, which is particularly difficult and highly subject to error (Casselman, 1983). Hence, definitive conclusions can only be obtained based on the results of studies using more robust validation methods, such as those involving chemical staining of bone structure.

The back-calculated lengths indicated the presence of the Rosa-Lee phenomenon in the population studied. Several hypotheses have been offered to explain this phenomenon, the main ones being: biased sampling, technical problems (incorrect use of the correlation between spine size versus body size), size-dependent mortality (natural or by fishing) (Ricker, 1969, 1979), and spatial stratification of the different ontogenetic phases (Stanley, 1980). The Rosa-Lee phenomenon in the species studied here appears to be the result of biased sampling. Although there are few published studies describing the shape of the selectivity curve for fishing hooks, some authors suggest that it is bell-shaped (Gayanilo Jr. \& Pauly, 1997; Sparre \& Venema, 1997). Under such conditions, if one assumes that the age groups making up the population present normal distribution sizes, in this study only the larger individuals (the right-hand tail of the curve) would be included in the age group displaying 1 annulus. Slow-growing individuals would only be included in the analysis when there are 2 annuli. The result is that the older the individual, the smaller the size estimated for its first year of life.

Although the value of k estimated for S. lima indicates slow growth, the size attained at the end of the first year is not. High growth rates in the first year have been determined for other predator fish species (all the above listed Pimelodidae). This strategy seems to enable ichthyophagous fish to feeding on the juvenile cohorts of their habitual prey 
as they grow (Araújo \& Haimovici, 2000). Moreover, rapid growth during the first year of life may ensure that smaller predators escape from larger ones, since they are all limited by the size of their mouth.

The estimates of the growth parameters presented here serve as a basis for future assessment of the stock of $S$. lima in the Cuiabá River. It is not known, however, if these estimates can be extrapolated to the entire Pantanal region. After all, the Pantanal floodplain is formed by the periodic flooding of the Paraguay River and its tributaries. Each tributary displays a specific flooding pattern (Hamilton et al., 1996). The characteristics and pressure of fishing vary from one river to another (Catella, 2001). Therefore, this complex of ecosystems raises the question of how the regional fish populations are structured. Does each river have its own stock of $S$. lima, or is there just one stock for the entire Pantanal? The answer to this question is urgent and should be useful in devising more efficient fishery management strategies for the region.

Acknowledgments - We are grateful to CAPES for scholarships for the first two authors; to an anonymous referee for comments about the text, and to Dr. M. Petrere Júnior (Unesp, Rio Claro) for English revision.

\section{REFERENCES}

ALONSO, J. C., 1998, Pesca e esforço de pesca dos grandes bagres (Siluriformes: pimelodidae) num setor colombiano do Alto Amazonas. Dissertação de mestrado, Instituto Nacional de Pesquisas da Amazônia, 78p.

ARAÚJO, J. N. \& HAIMOVICI, M., 2000, Determinação de idades e crescimento do linguado branco Paralichthys patagonicus (Jordan, 1889) no sul do Brasil. Rev. Brasil. Ocean., 48: 61-70.

BAYLEY, P. B. \& PETRERE Jr., M., 1989, Amazon fisheries: assessment methods, current status and management options. In: D. P. Dodge (ed.), Proceedings of the International Large River Symposium. Can. Spec. Publ. Fish. Aquat. Sci., 106: 385-398.

BERTALANFFY, L. V., 1938, A quantitative theory of organic growth (Inquiries on growth laws. II). Human Biology, 10: 181-213.

BRENNAN, J. S. \& CAILLIET, G. M., 1989, Comparative agedetermination techniques for White Sturgeon in California. Trans. Am. Fish. Soc., 118: 296-310.

BRITSKI, H. A., SILIMON, K. Z. S. \& LOPES, B. S., 1999, Peixes do Pantanal. EMBRAPA-SPI, Brasília; EMBRAPACPAP, Corumbá, $184 \mathrm{p}$.

BURGESS, W. E., 1989, An atlas of freshwater and marine catfishes: a preliminary survey of the Siluriformes. T. F. H. Publications, New Jersey.
CAMPANA, S. E., 2001, Accuracy, precision and quality control in age determination, including a review of the use and abuse of age validation methods. J. Fish Biol., 59: 197-242.

CASSELMAN, J. M., 1983, Age and growth assessment of fish from their calcified structures - techniques and tools. NOAA Technical Report NMFS , 8: 1-17.

CATELlA, A. C., 2001, A pesca no Pantanal de Mato Grosso do Sul, Brasil: descrição, nível de exploração e manejo (1994-1999). Tese de Doutorado, Instituto Nacional de Pesquisas da Amazônia, 351p.

DA SILVA, C. J., 2000, Ecological basis for the management of the Pantanal - Upper Paraguay river basin. In: A. J. M. Smits, P. H. Nienhuis \& R. S. E. W. Leuven (eds.), New approaches to river management. Backhuys Publishers, Leiden, The Netherlands, pp. 97-117.

DA SILVA, C. J. \& ESTEVES, F. A., 1995, Dinâmica das características limnológicas das baías Porto de Fora e Acurizal (Pantanal de Mato Grosso) em função da variação do nível da água. Oecologia Brasiliensis, 1: 47-60.

FENERICH, N. A., NARAHARA, M. Y. \& GODINHO, H. M., 1975, Curva de crescimento e primeira maturação sexual do mandi, Pimelodus maculatus Lac. 1803 (Pisces, Siluroidei). Bol. Inst. Pesca, 4: 1-28.

FERRAZ DE LIMA, J. A., 1986, A pesca no Pantanal de Mato Grosso (Rio Cuiabá: importância dos peixes migradores). Acta Amazônica, 16/17: 87-94.

FERRAZ DE LIMA, J. A. \& CHABALIN, E., 1984, O mercado de peixes de Cuiabá (Estrutura econômico-social). Secretaria Municipal de Serviços Públicos, Prefeitura Municipal, Cuiabá, 96p.

FRANCIS, R. I. C. C., 1990, Back-calculation of fish length: a critical review. J. Fish Biol., 36: 883-902.

FROESE, R. \& PAULY, D. (eds.), 2002, Fishbase. World Wide Web eletronic publication: www.fishbase.org, 15 Mar. 2002.

GAYANILO Jr., F. C. \& PAULY, D., 1997, FAO-ICLARM stock assessment tools (FISAT): reference manual. FAO Computerized Information Series (Fisheries) Rome, 8: 262.

GOULDING, M., 1981, Man and fisheries on an Amazon frontier. The Hague, Dr. W. Junk, 222p.

HAMILTON, S. K., SIPPEL, S. J. \& MELACK, J. M., 1996, Inundation patterns in the Pantanal wetland of South America determined from passive microwave remote sensing. Arch. Hydrobiol., 137: 1-23.

HECKMAN, C. W., 1994, The seasonal succession of biotic communities in wetlands of the tropical wet-and-dry climatic zone: I. Physical and chemical causes and biological effects in the Pantanal of Mato Grosso, Brazil. Int. Revue Ges. Hydrobiol., 79: 397-421.

KÖPPEN, G. W., 1948, Climatologia. Fundo de Cultura Econômica, México.

LAI, H. L., GALLUCCI, V. F., GUNDERSON, D. R. \& DONNELLY, R. F., 1996, Age determination in fisheries: methods and applications to stock assessment, pp. 82-178. In: V. F. Gallucci, S. B. Saila, D. J. Gustafson \& B. J. Rothschild (eds.), Stock assessment: quantitative methods and applications for small-scale fisheries. CRC Press, Florida, 527p. 
LEE, R., 1912, An investigation into the methods of growth determination in fishes. Cons. Int. Explor. Mer Publ. Circonstance, 63: 34.

LITTMANN, M. W., BURR, B. M., SCHMIDT, R. E. \& ISERN, E. R., 2001, Sorubim elongatus, a new species of catfish (Siluriformes: Pimelodidae) from tropical South America syntopic with S. lima. Ichthyol. Explor. Freshwaters, 12: 1-16.

LOUBENS, G. \& PANFILI, J., 2000, Biologie de Pseudoplatystoma fasciatum et $P$. tigrinum (Teleostei: Pimelodidae) dans le bassin du Mamoré (Amazonie Bolivienne). Ichthyol. Explor. Freshwaters, 11: 13-34.

LOWE-McCONNELL, R. H., 1999, Estudos ecológicos de comunidades de peixes tropicais. EDUSP (coleção base), São Paulo, 534p.

MAGO, F. M. L., 1970, Estudios preliminares sobre la ecología de los peces de los llanos de Venezuela. Acta Biologica Venezuelica, 7: 71-102.

MATEUS, L. A. F. \& PETRERE Jr., M. (in press), Age, growth and yield per recruit of pintado Pseudoplatystoma coruscans in Cuiabá River Basin, Pantanal of Mato Grosso, Brazil. Braz. J. Biol., 64(3).

McFARLANE, G. A. \& KING, J. R., 2001, The validity of the fin-ray method of age determination for lingcod (Ophiodon elongatus). Fish. Bull., 99: 459-464.

MEGALOFONOU, P., 2000, Age and growth of Mediterranean albacore. J. Fish Biol., 57: 700-715.

MUÑOZ-SOSA, D. L., 1996, Age structure and exploitation of Giant Catfish populations (Brachyplatystoma spp.) in the Lower Caqueta River, Colômbia. Master thesis, College of Environmental Science and Forestry, State University of New York, 100p.

NOVOA, D. F., 1982, Los recursos pesqueros del río Orinoco y su explotación. Corporación Venezolana de Guayana, Caracas,

PÉREZ LOZANO, A. P., 1999, Idade e crescimento da piracatinga Calophysus macropterus, Lichtenstein, 1819 (Pisces: pimelodidae), na Amazônia Central. Dissertação de Mestrado, Instituto Nacional de Pesquisas da Amazônia, 89p.

PETRERE Jr., M., 1989, River fisheries in Brazil: a review. Regulated rivers: research and management, 4: 1-16.

PETRERE Jr., M., AGOSTINHO, Â. A., OKADA, E. K. \& JÚLIO Jr., H. F., 2002, Review of the fisheries in the Brazilian portion of the Paraná/Pantanal basin. In: I. G. Cowx (ed.), Management and ecology of lake and reservoir fisheries. Blackwell Science, Fishing News Books, Oxford, pp. 123-143.

REID, S., 1983, La biología de los bagres rayados Pseudoplatystoma fasciatum y $P$. tigrinum en la cuenca del Río Apure, Venezuela. Rev. UNELLEZ Cien. Tecnol., 1: 13-41.

REINA, M. P., RAMÍREZ, H. \& VALDERRAMA, B. M., 1995, Edad y crecimiento de Paulicea lüetkeni (Steindachner, 1876) (Pisces: Pimelodidae) basado en la lectura de estructuras duras (espinas de aleta pectoral) en el Alto Río Meta (Colombia). Boletín Científico INPA, 3: 115-135.
RESENDE, E. K., CATELlA, A. C., NASCIMENTO, F. L., PALMEIRA, S. S., PEREIRA, R. A. C., LIMA, M. S. \& ALMEIDA, V. L. L., 1996, Biologia do curimbatá (Prochilodus lineatus), pintado (Pseudoplatystoma corruscans) e cachara (Pseudoplatystoma fasciatum) na bacia hidrográfica do rio Miranda, Pantanal do Mato Grosso do Sul, Brasil. EMBRAPA-CPAP (Boletim de Pesquisa, 2), Corumbá, 75p.

RIBEIRO, M. C. L. B., PETRERE Jr., M. \& JURAS, A. F., 1995 , Ecological integrity and fisheries ecology of the AraguaiaTocantins River basin, Brazil. Regulated Rivers: Research \& Management, 11: 325-350.

RICKER, W. E., 1969, Effects of size-selective mortality and sampling bias on estimates of growth, mortality, production and yield. J. Fish. Res. Board Can., 26: 479-451.

RICKER, W. E., 1979, Growth rates and models. In: W. S. Hoar, D. J. Randall \& J. R. Brett (eds.), Fish physiology Vol. VIII: Bioenergetics and growth. Academic Press, Flórida, pp. 677743.

RICKER, W. E., 1992, Back-calculation of fish lengths based on proportionality between scale and length increments. Can. J. Fish. Aquat. Sci., 49: 1018-1026.

RIEN, T. A. \& BEAMESDERFER, R. C., 1994, Accuracy and precision of White Sturgeon age estimates from pectoral fin rays. Trans. Am. Fish. Soc., 123: 255-265.

SOKAL, R. R. \& ROHLF, F. J., 1995, Biometry. W. H. Freeman and Company, New York, Third edition, 887p.

SPARRE, P. \& VENEMA, S. C., 1997, Introdução à avaliação de mananciais de peixes tropicais. FAO (Documento Técnico sobre as Pescas 306/1, Rev. 2. Parte 1: manual), Roma, 404p.

STANLEY, C. A., 1980, Lee's phenomenon in the western subspecies of the australian salmon, Arripis trutta esper. Aust. J. Mar. Freshwater Res., 31: 13-19.

SYSTAT, 1997, Version 7.0. SPSS Science, Chicago, Illinois, USA.

TAYLOR, C. C., 1957, Cod growth and temperature. Journal du Conseil, 23: 366-370.

VAZZOLER, A. E. A. M., SUZUKI, H. I., MARQUES, E. E. \& LIZAMA, M. A. P., 1997, Primeira maturação gonadal, períodos e áreas de reprodução, pp. 249-265. In: A. E. A. M. Vazzoler, A. A. Agostinho \& N. S. Hahn (eds.), A planície de inundação do Alto Rio Paraná: aspectos físicos, biológicos e socioeconômicos. EDUEM, Maringá, 460p.

WELCOMME, R. L., 1992, Pesca fluvial. FAO (Documento Técnico de Pesca 262), Roma, 303p.

ZAR, J. H., 1996, Biostatistical analysis. Prentice Hall, New Jersey, Third edition. 